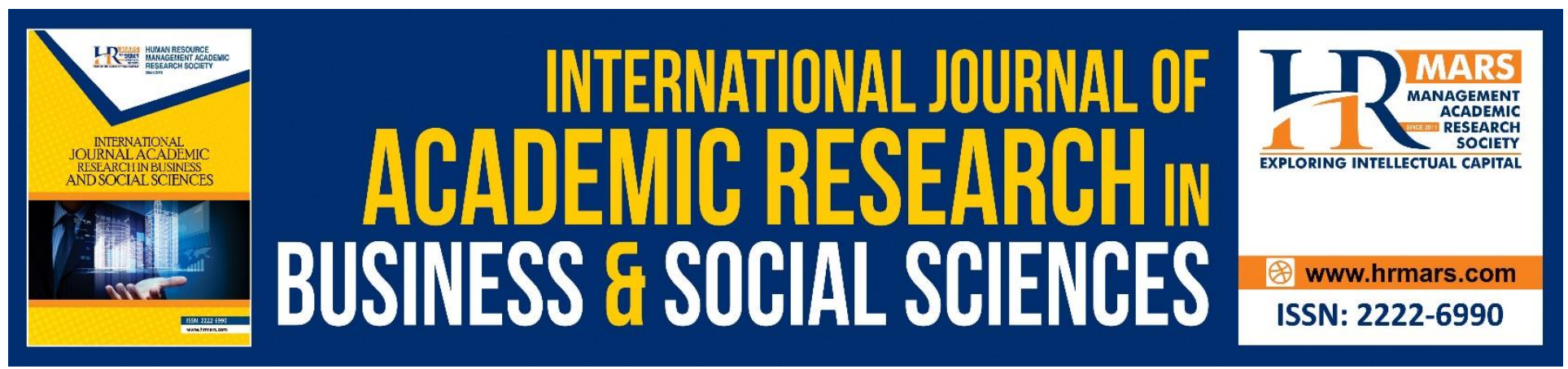

\title{
Knowledge Transfer Program Implementation: A Review of Selected Countries
}

\author{
Azlinda Azman, Siti Rahyla Rahmat, Saidatulakmal Mohd \& Mohamad \\ Shaharudin Samsurijan
}

To Link this Article: http://dx.doi.org/10.6007/IJARBSS/v8-i11/4932

DOI: $10.6007 /$ IJARBSS/v8-i11/4932

Received: 08 Sept 2018, Revised: 21 Oct 2018, Accepted: 16 Nov 2018

Published Online: 28 Nov 2018

In-Text Citation: (Azman, Rahmat, Mohd, \& Samsurijan, 2018)

To Cite this Article: Azman, A., Rahmat, S. R., Mohd, S., \& Samsurijan, M. S. (2018). Knowledge Transfer Program Implementation: A Review of Selected Countries. International Journal of Academic Research in Business and Social Sciences, 8(11), 589-597.

\section{Copyright: (C) 2018 The Author(s)}

Published by Human Resource Management Academic Research Society (www.hrmars.com)

This article is published under the Creative Commons Attribution (CC BY 4.0) license. Anyone may reproduce, distribute, translate and create derivative works of this article (for both commercial and non-commercial purposes), subject to full attribution to the original publication and authors. The full terms of this license may be seen

at: http://creativecommons.org/licences/by/4.0/legalcode

\section{Vol. 8, No. 11, 2018, Pg. 589 - 597}

Full Terms \& Conditions of access and use can be found at http://hrmars.com/index.php/pages/detail/publication-ethics 


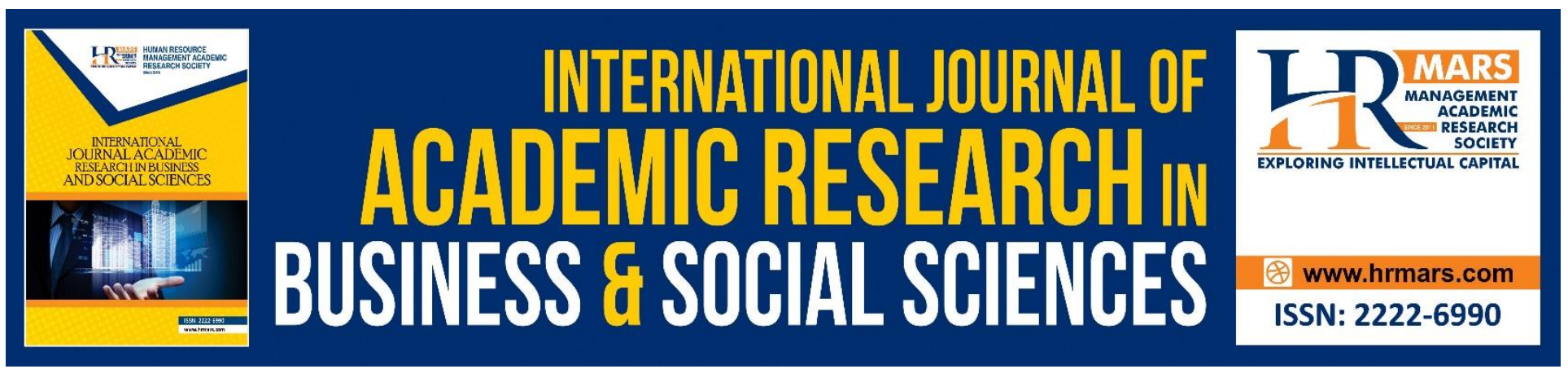

\title{
Knowledge Transfer Program Implementation: A Review of Selected Countries
}

\author{
Azlinda Azman, Siti Rahyla Rahmat, Saidatulakmal Mohd \& \\ Mohamad Shaharudin Samsurijan \\ School of Social Sciences, Universiti Sains Malaysia, Malaysia
}

\section{Abstract}

This paper proposes a new element in a quintuple helix concept to extemporize a current practices of the Knowledge Transfer Program (KTP) in Malaysia. This study examines the current KTP practiced in Malaysia and other selected countries. The content analysis of selected countries shows that most are adapting and adopting either the triple helix concept or quadruple helix concept in their current practices to make use of the knowledge sharing between academia-industry, academia-community and academia-graduate intern- industry-community. Some KTPs did not clearly shows in their model the importance of natural environment, but we believe the marginal effect will indirectly benefit the natural environment and the sustainability of the countries. The adaptation and adoption of the quadruple helix concepts are relevant, but the extent to which it is implemented in KTP when taking into account the natural environment remains vague and not clearly stated in most of the countries. Keywords: Knowledge Transfer, Quintuple Helix, Quadruple Helix, Academia, Industry

\section{Introduction}

Knowledge is a key measure of a nation's development. Knowledge is the source of achieving, maintaining and sustaining economic growth and competitive market advantage in a country (Courtney \& Anderson, 2009). Knowledge, if properly harnessed and leveraged can propel organisations to become more adaptive, innovative, intelligent and sustainable (Wong \& Elaine, 2004). As we move further into globalisation, the importance of knowledge and the way of delivering the knowledge are magnified.

Knowledge transfer, also known as knowledge sharing, is a systematically organised approach to exchanging information and skills between people or two business units (Liyanage, Ballal, Elhag \& $\mathrm{Li}, 2009)$. It is one of the best ways for development and innovation. According to [19], many firms are learning to use a consultant but could become dependent on them when they fail to transfer knowledge into the firm. This reflects the importance of knowledge transfer to leverage intellectual capital (Ulrich, 1998). 
This paper objectives are 1) To understand the current practices of KTP in the selected countries 2) To identify if there is a gap in the current practices based on helix models 3) To propose new element in quintuple helix concept to spark the current KTP practices for Malaysia and other countries.

Malaysia is chosen as Malaysia's KTP is still at the infant stage and in a process to improvise its current practice. UK is chosen in this study as the knowledge transfer between industry-academia is important in UK's industrial strategy (Times Higher Education, 2018). In addition, Ireland Knowledge Transfer Program was lay out as the National IP Protocol in 2016. As for Korea, KTP represents a key element of its knowledge - intensive development cooperation program.

This paper introduces the current practices and key players of each Knowledge Transfer Program (KTP) in selected countries and compare if there are some differences. At the end of the paper, the knowledge transfer practices between academia-industry, academia-graduate internindustry/ community and academia-community in Malaysia, Korea, United Kingdom and Ireland are discussed and compared to see if there is any difference between these selected countries and how to improvise the current practices.

\section{Triple Helix, Quadruple Helix and Quintuple Helix Triple Helix}

Universities and industry, up to now relatively separate and distinct institutional spheres, are assuming tasks that were formerly restricted to the purview of each institution separately. The role of government in relation to these two spheres is changing in apparently contradictory directions. Governments are offering incentives, on the one hand, and pressing academic institutions, on the other, to go beyond performing the traditional functions of cultural memory, education and research, and make a more direct contribution to "wealth creation" (UK Government, 2015). This change can be related to the Triple Helix which is used as the model for the knowledge-based economy which consists of three main institutions, namely university, industry, and government (Etzkowitz \& Leydesdorff, 1995).

The Triple Helix model allows the process of creating and knowledge transfer as a result of the interaction between the research units, industry and the governmental sphere, e.g., entities shaping country development policy which leads to innovation (Kurowska-Pyzs \& Walanci, 2017).

\section{Quadruple Helix}

In the Quadruple Helix approach, (Arnkil, Jarvensivu, Koski \& Piirainen, 2010) stress the need to enlarge the innovation concept of the Triple Helix model with a societal perspective. One of the reasons that drive to the addition of the fourth sphere is simply because the increase of global competition means companies can no longer solely depend on the price and quality of the product for sales. Thus, companies must seek alternative competition advantages and transform their innovation process to deliver better products and services to the market by understanding the needs of the consumer and the direct involvement of users. Innovation will then be made according to the user's need and users will give their feedback on the products and services and contribute regarding knowledge, inventiveness and creativity (Cavallini, Soldi, Friedl \& Volpe, 2016). 
INTERNATIONAL JOURNAL OF ACADEMIC RESEARCH IN BUSINESS AND SOCIAL SCIENCES

Vol. 8, No. 11, Nov, 2018, E-ISSN: 2222-6990 @ 2018 HRMARS

\section{Quintuple Helix}

In the year 2010, both Carayannis and Campbell developed the Quadruple Helix by including the fifth helix which is the natural environment and developing it into the Quintuple Helix model as shown in Figure 1. The Quintuple Helix is a model which grasps and specialises the sum of the social (societal) interactions and the academic exchanges in a state (nation-state) in order to promote and visualise a cooperation system of knowledge, know-how, and innovation for more sustainable development (Carayannis \& Campbell, 2010). By including the natural environment as a new subsystem to the knowledge and innovation model, "the knowledge production and creation of new innovation will be crucial for preservation, survival, vitalisation of humanity and the possible inventions of new green technologies" (Carayannis, Barth \& Campbell, 2012) (Figure 1)

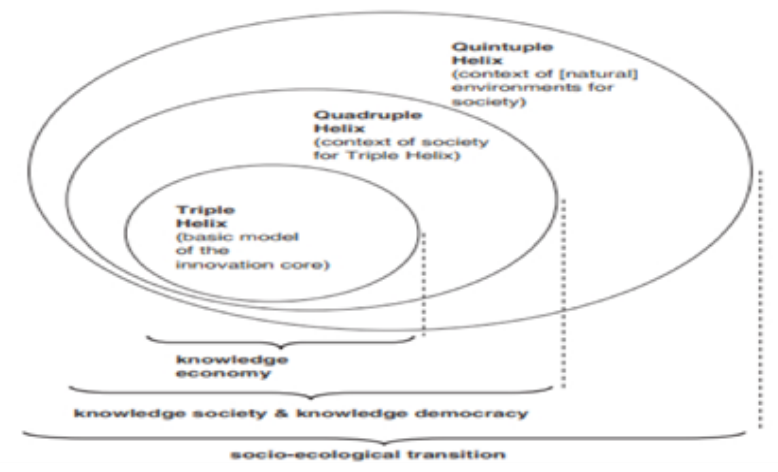

Figure1: Knowledge production and innovation (Carayannis et al., 2012)

\section{KTP in Malaysia}

KTP in Malaysia is an initiative under the $10^{\text {th }}$ Malaysia Plan to strengthen the network between industry-community and collaboration with academia where the government emphasises strengthening the industry and research collaboration while also focusing on industrial attachments (Salleh \& Omar, 2013). The objective of this program is to recognise and promote the transfer of knowledge through the exchange of creative and innovative ideas, research findings, experience and skills between the public university (IPTA), research organisations, industries, government agencies and the wider community.

\section{KTP in Korea}

In 2004, the Ministry of Finance and Economy launched the Korea Sharing Program (KSP), a cooperation program where Korea shares its experience, skills and knowledge through research and policy with the Korea Development Institute (KDI) playing a key role. This program has three main objectives. The first objective is to seek practical solutions to current problems faced by developing countries and help them overcome development obstacles. The second goal is to enhance policy making and management capabilities of the partner countries so that they can establish effective policymaking to initiate development momentum. The last objective is to recognise the value of knowledge and its two-way flow. The Policy Consultation for Partner Countries seeks to nurture 
INTERNATIONAL JOURNAL OF ACADEMIC RESEARCH IN BUSINESS AND SOCIAL SCIENCES

Vol. 8, No. 11, Nov, 2018, E-ISSN: 2222-6990 @ 2018 HRMARS

mutually beneficial relationships that will become valuable assets for future cooperation (Kim \& Tcha, 2012).

\section{KTP in the United Kingdom}

KTP in the United Kingdom is known as Knowledge Transfer Partnership and is funded partly by the UK government and Innovate UK plays a critical role in this program. Innovate UK or formerly known as The Technology Strategy Board (TSB), is a brokerage organisation that enables companies, industry, academia to collaborate on innovative projects. A KTP enables a business to bring in new skills and the latest academic thinking to deliver a specific, strategic innovation project through a knowledge-based partnership. It allows the businesses to develop better as they can obtain academic expertise that they do not have in-house. There are three partnerships in this program which is between businesses, academia and graduate. The academic institution employs the recentlyqualified graduate who works at the company. The graduate, known as the 'associate', brings new skills and knowledge to the business. A KTP can last between 12 and 36 months depending on the project and the needs of the business. It is part-funded by a grant where the businesses will have to contribute to the salary of the associate and the cost of the supervisor (UK Government, 1993).

\section{KTP in Ireland}

Ireland has built up a prominent infrastructure, expertise and international reputation for scientific research and innovation during recent decades. According to the Minister for Jobs, Enterprise and Innovation, Ireland is currently ranked $10^{\text {th }}$ out of 142 countries for innovation, while ranked first out of 23 countries in Europe in terms of knowledge transfer performance of public research organisations.

In 2013, Ireland launched its KTP known as Knowledge Transfer Ireland (KTI) with the aim to help businesses to benefit by accessing Irish expertise and technology and making it simple to connect and engage with the research base in Ireland. The key element for the KTI is the engagement of research organisations with business $\&$ industry and investors. There are three distinct types of activities involved which include research activities, knowledge transfer activities, and economic activities which are performed in principle by different actors with different skills, goals, responsibilities, and inclinations. The research outputs including new knowledge. The researchers are the pivotal actors who transfer the economic sphere into other economic processes along with other actors (Finne, Adrian, Andrea, Andre, Patricia \& Dorien, 2011).

\section{Methodology}

The analysis is based on existing literature review on the implementation of KTP in the selected countries. Document and content analysis were carried out to come up with a thorough comparison analysis.

\section{Results and Discussion}

\section{Analysis on the Implementation of KTP}

Analysis on the implementation of KTP in the sampled countries are divided into three categories which are presented in the following discussion. 


\section{Knowledge Transfer Academia-Industry}

University-industry knowledge transfer activities involve various institutional interactions, along with the government role help to create and promote firm competitiveness using and effective generation of knowledge (Wang \& Lucy, 2007). Due to that, Malaysia's KTP has set a goal to apply knowledge for industry development and to ensure that Malaysia meets the goal through a series of workshop/seminar and CEO talks as a strategy to enhance and upgrade industrial value chain. In Korea, a dialogue, seminar and meeting will be held as one a medium to share the knowledge among experts with others. This is known as the Korean Exchange Forum (Lim, 2015). To share current practices, needs and requirement of industries, a feedback portal and focus group discussion (FGD) with industry will form part of the action plan following Korea which introduced the Knowledge Sharing Program with partner countries where in surveys are sent via the Korean embassy to an agency/organisation in a potential partner country (Lim, 2015). In the UK, KTP databases are provided by Innovate UK followed by guide notes, recommendations and workshops. The same action plan was practised in Ireland where KTI welcomes an open dialogue with their stakeholders.

\section{Knowledge Transfer Academia-Community}

Knowledge Transfer involves elements or key players as depicted in the triple helix, quadruple helix and quintuple helix concepts. Malaysia's KTP model states that community is an important element. Research is a useful tool which acts as a catalyst to improve community development. Due to that, community outreach through a series of hands-on activities is needed. Ireland believes that the knowledge transfer activity of academia is to turn students into graduates and let the students share their knowledge with society and the labour market. Furthermore, teaching and continued professional development (CPD) refers to the training of people who then share the knowledge with the society (Finne et al., 2011) Korea and the UK did not discuss the community aspect in detail, but it is believed that the marginal effect of their respective initiatives will indirectly benefit the community.

\section{Knowledge Transfer Academia-Graduate Intern-Industry/Community}

Another goal that is important in Malaysia's KTP is to enhance graduate/intern experience with the industrial practices and learn, re-learn, co-learn and co-create between the graduate/intern and community. For instance, DRB HICOM BERHAD established the DRB -HICOM University (DHU) in 2016 to produce skilled professionals to join the workforce. The university combines the practical experience with a theory which will equip their students with tangible skills. In the UK, a qualified graduate will conduct a project jointly supervised by the industry and the university. The qualified graduate will then work in the industry for between one to three years to implement the project (Jones-Evans, 2007).

In addition, to ensure this KTP will sustain and benefit all key players, it is necessary to strengthen the internal and external networking involving all the key players. KSP in Korea works together with the Export-Import Bank (EXIM Bank) of Korea and Korea International Cooperation Agency (KOICA) to conduct a preliminary country study and secure support for their activities with the help of local representative offices in the partner country (Lim, 2015). While in the UK, the overall number of active KTPs has increased since the early 1990s and there are currently 963 active partnerships. The 
INTERNATIONAL JOURNAL OF ACADEMIC RESEARCH IN BUSINESS AND SOCIAL SCIENCES

Vol. 8, No. 11, Nov, 2018, E-ISSN: 2222-6990 C 2018 HRMARS

duration of each partnership started between 1981 and 1990 lasted for three and a half years on average, and those started in 2004/05 were a year shorter (Regeneris Consulting, 2010).

\section{Limitations of The Study}

This study is based on document and content analysis retrieved from the past researches, which may be limited in the practical understanding of the implementation of KTP in the sampled countries.

\section{Conclusion}

Following the discussions above, it can be seen that all the KTPs in Malaysia, Korea, the United Kingdom and Ireland have similar objectives which are to strengthen the relationship between academia and industry and make use of knowledge to improve competitiveness and productivity as well as become more innovative.

Based on the content analysis for Malaysia, Korea, the United Kingdom and Ireland, all countries adopt and adapt both the triple helix and quadruple helix concept in the KTPs. Similar to Korea, the United Kingdom and Ireland, Malaysia's knowledge transfer for academia-industry aims to apply research knowledge for industry development through a series of workshop/seminars and CEO talks. Malaysia needs to prioritise the academia-community knowledge transfer as research acts as a catalyst to improve community development. As for the knowledge transfer between academiagraduate intern-industry/community, Malaysia needs to improve graduate/intern experience with industrial practices.

In conclusion, most of the sampled countries focus on the same element in their KTP model. The key players in each model are research organisations, industries or companies and graduate/interns. Only Ireland does not have a graduate/intern element, and the countries did not focus on the community aspect. Following that, Malaysia has taken a step ahead by focusing on community directly in its KTP framework. However, Malaysia's KTP or other countries may need to consider the fifth element in Quintuple Helix Model namely natural environment in their KTP framework clearly. There might already took into account a natural environment element but did not clearly stated in their KTP framework.

\section{Acknowledgement}

The authors gratefully acknowledge the financial support from Ministry of Higher Education and Knowledge Transfer Programme Secretariat for the funding received under the KTP Research Programme titled Establishing a KTP Programmatic Framework for Project Engagement and Integration with National Level Policies and Concepts (project code: K-KTP/05(USM-15).

\section{Corresponding Author}

Siti Rahyla Rahmat, School of Social Sciences, Universiti Sains Malaysia 11800, Penang, Malaysia

\section{References}

Arnkil, R., Järvensivu, A., Koski, P., \& Piirainen, T. (2010). Exploring quadruple helix: Outlining useroriented innovation models. Final Report on Quadruple Helix Research for the CLIQ Project.

Carayannis, E. G., \& Campbell, D. F. (2010). Triple Helix, Quadruple Helix and Quintuple Helix and how 
INTERNATIONAL JOURNAL OF ACADEMIC RESEARCH IN BUSINESS AND SOCIAL SCIENCES Vol. 8, No. 11, Nov, 2018, E-ISSN: 2222-6990 @ 2018 HRMARS

do knowledge, innovation and the environment relate to each other?: A proposed framework for a trans-disciplinary analysis of sustainable development and social ecology. International Journal of Social Ecology and Sustainable Development (IJSESD), 1(1), 41-69.

Carayannis, E. G., Barth, T. D., \& Campbell, D. F. (2012). The quintuple helix innovation model: Global warming as a challenge and driver for innovation. Journal of Innovation and Entrepreneurship, 1(1), 2. doi:10.1186/2192-5372-1-2.

Cavallini, S., Soldi, R., Friedl, J., \& Volpe, M. (2016). Using the quadruple helix approach to accelerate the transfer of research and innovation results to regional growth. European UnionCommittee of the Regions. doi:10.2863/408040.

Courtney, L. and Anderson, N. (2009). Knowledge transfer between Australia and China. Journal of Knowledge-Based Innovation in China, 1(3), 206-25. doi:10.1108/17561410910990584.

Etzkowitz, H., and Leydesdorff, L. (1995). The triple helix --- university-industry-government relations: A laboratory for knowledge based economic development. EASST Review, 14(1), 14-19.

Finne, H., Adrian D., Andrea P., André S., Patricia W., and Dorien W. (2011). A composite indicator for knowledge transfer. Report from the European Commission's Expert Group on Knowledge Transfer Indicators.

Finnish Ministry of Employment and the Economy. (2009). Demand and User-Driven Innovation Policy.

Jones-Evans, D. (2007). Entrepreneurship Environment and Policies: Exploiting the Science and Technology Base in the Region of Halle. Retrieved from OECD Local Entrepreneurship website: http://www.oecd.org/site/cfecpr/38795732.pdf

Kim, Y., \& Tcha, M. (2012). Introduction to the knowledge sharing program (KSP) of Korea. Washington, U.S: Korea Economic Institute.

Kurowska-Pysz, J. and Walanci, M. (2017). The relationships in the process of knowledge transfer according to the triple helix model. European Journal of Economics and Business Studies, 9(1).

Lim, W. H. (2015). Korea's knowledge sharing program (KSP). Joint US-Korea Academic Studies.

Liyanage, C., Ballal, T., Elhag, T. and Li, Q. (2009). Knowledge communication and translation - a knowledge transfer model. Journal of Knowledge Management, 13(3), 118-31. doi:10.1108/13673270910962914

Regeneris Consulting. (2010). Knowledge transfer partnerships strategic review. Regeneris Consulting Ltd.

Salleh, M.S., \& Omar, M.Z. (2013). University-Industry collaboration models in Malaysia. Procedia Social and Behavioral Sciences 102, 654-64. doi:10.1016/j.sbspro.2013.10.784

Times Higher Education. (2018). Research that pays: knowledge transfer at the world's top universities. Retrieved from www.timeshighereducation.com/features/research-paysknowledge-transfer-worlds-top-universities

UK Government. (2015). Knowledge transfer partnerships: What they are and how to apply. Retrieved from www.gov.uk/guidance/knowledge-transfer-partnerships-what-they-are-andhow-to-apply.

UK Government. (1993). Realising our potential: A strategy for science, engineering and technology. Retrieved from www.gov.uk/government/publications/realising-our-potential-a-strategyfor-science-engineering-and-technology. 
INTERNATIONAL JOURNAL OF ACADEMIC RESEARCH IN BUSINESS AND SOCIAL SCIENCES

Vol. 8, No. 11, Nov, 2018, E-ISSN: 2222-6990 @ 2018 HRMARS

Ulrich, D. (1998). Intellectual capital = Competence $X$ commitment. Retrieved from https://sloanreview.mit.edu/article/intellectual-capital-competence-x-commitment/.

Wang, Y., and Lucy L. (2007). Knowledge transfer through effective university-industry interactions. Journal of Technology Management in China 2(2), 119-33. doi:10.1108/17468770710756068

Wong, K. Y., \& Elaine, A. (2004). Characterizing knowledge management in the small business environment. Journal of Knowledge Management 8(3), 44-61. doi:10.1108/136732704105410 